\title{
Public Perception of the Implementation of Simultaneous Regional Head Election 2020 during Covid-19 Pandemic in Palangka Raya Regency
}

\author{
Jhon Retei Alfri Sandi ${ }^{1}$, Suprayitno ${ }^{2}$, Imanuel Jaya ${ }^{3}$ \\ ${ }^{1,2,3}$ Faculty of Social and Political Sciences, Universitas Palangka Raya, Indonesia \\ suprayitno@fisip.upr.ac.id
}

\begin{abstract}
Central Kalimantan is one of the provinces in Indonesia will implement the Regional Election simultaneously on December 9, 2020. There are 2 (two) Regional Elections, they are Governor and Deputy, and Mayor and Deputy in Kotawaringin Timur Regency. On December 2020, at least 270 Regions would participate to Regional Elections in Indonesia, including provincials, Regencies, and Cities. The democracy atmosphere implementation would be different from previous over the years due to COVID-19 Pandemic as its prediction. This research aims to disclose Palangka Raya Public Perceptions of Regional Election in Covid-19 Pandemic recently. Majority Respondents agree to implement the Regional Election in Palangka Raya on December 9. Furthermore, The Regional Election could be implemented by following the Protocol Health Procedures with safe and healthy against Covid-19.
\end{abstract}

Keywords

regional election; perception; society, covid-19

\section{Introduction}

The fundamental characteristic of a democratic system is the general elections. The elections are not the only aspect of democracy, but they become an important part due to elections act as a mechanism for political change regarding the pattern and direction of public policies or the periodic and orderly circulation of elites (Surbakti, 2008).

Since 2005, Indonesia has implemented a system of direct election for local leader (Pilkada langsung). Direct local leader elections were held simultaneously starting in 2015, 2017, and 2018, and, the newest that will be held on 9 September 2020. Pandemic coronavirus disease 2019 or abbreviated as Covid-19, which hit the world-wide and Indonesia in early March 2020, forced the Indonesian KPU (General Elections Commission) to stop the stages of elections through KPU RI Decree No. 179/2020 concerning Postponement of Elections for Governors, Regents, and Mayors in preventing Covid-19.

Elections become a means of aggregating people's aspirations in expressing the will to chose the individuals who represent them to sit in political representative institutions and government. People are an important part of democracy because of their role and participation in the election is an important indicator of the success of the election.

Surbakti Ramlan \& Hari Fitrianto (2015: 9) argue that, ideally, democratic elections must meet 8 (eight) principles as in international standards, namely:

1. Periodic Elections; elections must be held at regular intervals as stipulated in law;

2. Genuine Elections; elections must be held in a conducive socio-political environment, where human freedom is upheld and political pluralism grow;

3. Free Elections, namely free to choose; 
4. Fair Elections; elections must able to guarantee a fair contestation and uphold equality;

5. Universal Suffrage; elections must able to guarantee the right to vote and be elected by all elible people according to law;

6. Equal Suffrage is every citizen has one vote and the vote is measured with the same value, (one man, one vote, one value);

7. Voting by Secret Ballot; the elections must able to guarantee the confidentiality of the voters' choices;

8. Honest Counting and Reporting of Result; the election organizer when carrying out the task of counting votes, and tabulation of votes must act professionally, impartially, efficiently, and accurately.

Regional Election (Pilkada) is one of people's ride to involve their figure's voting and Regional Leadership in a particular period. Governor and Deputy 2021-2024 Period will be held on December 9, 2020 along with 270 Regionals in including Provincial, Regency, and City Election in Indonesia. Covid-1919 Pandemic has forced General Elections Commission (KPU) by assigning the Decree of Phase Discontinued Implementation No.179/PL.02$\mathrm{Kpt} / 01 / \mathrm{KPU} / \mathrm{III} / 2020$.

Enactment of Government Regulation in Lieu of Law No.2 of 2020 on the Third Amendment to Law No.1 of 2015 on the enactment of Government Regulation in Lieu of Law No. 1 of 2014 on the Election of Governors, Regents / Mayors Becomes Law, during the Covid-19 pandemic has revoked the KPU Decree No. 179 / PL.02-Kpt / 01 / KPU / III / 2020 and the Article 201A paragraph (2) ordered: 'The postponed simultaneous voting will be held in December 2020'.

As The Government Regulation in Lieu of Acts (Perpu) No. 2 Th.2020 which stipulates the continued implementation of Regional Election on December 2020 in endless Covid-19 Pandemic, which affected the social, economics, and psychologies. Covid-19 Health Protocol had become the current issues in its implementation for Organizing Committees, Regional Government, General Election Participants, and Society. Considering a "Genuine Elections" as a standard International Democracy Principles, means The General Election held in SocialPolitic conducive environment, where the Human Right freedom is revered and politic pluralism grew.

As can be seen from this research, it aims to illustrate public perception of Palangka Raya People related to Regional Election in Covid-19 Pandemic. Thus, the result of this research will be considered for decision makers and Organizing Committees in Regional Election on December 9, 2020.

\section{Review of Literature}

According to Salito W. Sarwono (2009), Perception is analysing information to be understood by sense (Rohmaul Listyana, 2015). Kennet A. Sereno and Edwar M. Bodaken stated that Perception is a tool that allows us to gain awareness around and environment. Likewise Philip Goodacre and Jennifer Follers, Perception is using mental process to identify stimulation (Muliyana, 2017).

Perception is a mental process to identify, evaluate, and respond any situation around. Knowledge, experience, and socio cultural orientation will define image and perspective of the problems. The difference of experience, analysing and knowledge, a framework describes the result of perception among individuals are different. Moreover, in Covid-19 current situation, it will state the perspective, manner, and behaviour to the Government Policies about Simultaneous Regional Election on December 2020. 
Public Perception is a re-process which undergoing by human in particular living area and providing positive and negative knowledge or idea for people around (Yusra, 2018). Kenneth K. Sereno dan Edward M. Bodaken dalam Mulyana (2017) breakdown perception into 3 (three) activities, they are: Selection, Organization, and Interpretation. Selection consist of sensation and attention, while organization close to interpretation. It is strictly to distinct all of those, because we did not know when one phase ends and the next phase begins and tends to be hold simultaneously (Muliyana, 2017). Perception is an individual process to vote, organize, and interpret the information to create or produce a meaningful description (Kotler, 1995).

Regional Election (Pilkada) is one of people's ride to involve their figure's voting and regional leadership in a particular period. If democracy attract the people's attention widely, it would be a vital to establish a regional leadership, then. Thus, possessing a leadership skills which reflect the will of people is a primary vision of regional election (Harahap, 2016). Regional election becomes a holder to put legitimacy in particular region and part of another general election. Therefore, a direct regional election is a method to deliver of people's democracy. Iryadi et al (2019) stated that sometimes people who are well-known and democratic also follow dirty ways to win inside political competition. For some political elites, democracy is perceived as a place to fight for popular support.

A simultaneous regional election is a process to create local accountability, political equality, and local responsiveness. It is said that local democracy includes participation and power relation are established on the people's sovereignty. On the other hand, the result of the Election is expected to bring some advantages for better social, politics and economics condition. A good election would create a better sustainable government. The democratic and professional regional election will lead to political change (Arifulloh, 2015).

According to Amrizal, et al (2018) political participation is the involvement of self, mental, thoughts and emotions or feelings of a person from various levels of political activity such as election activities of state leaders through elections as a form of awareness and responsibility of a person against government regulations or policies. Azhar (2018) stated that in the context of Indonesian politics, the imaging of political parties is often influenced by individual imagery. The dominance of personal image is often identified with the image of the institution. Maeanwhile Matondang and Lubis (2018) stated that political participation is the activity of a group of people to actively participate in political life, among others by choosing a state leader, directly or indirectly, influencing government action (public policy), this includes actions such as voting in general elections, attending public meetings, holding relations (contacting) or lobbying with government officials or members of parliament, becoming members of the party or one of the social movements with direct action and so on".

Since Covid-19 Pandemic stated as non-natural disaster based on President Decree No. 12 Th. 2020 date April 13, 2020 has discontinued implementation of regional election in Central Kalimantan and the whole Indonesia Region. It has to be written in Government Regulation No. 1 / 2014 about The Governor, Regent, and Mayor Election Article 120 Chapter (1) : when riots, security threat, natural disaster occurred in part or Whole Regional Election of Indonesia or other intrusion inflicts election phase cannot be implemented, then continued Election would be the alternative way. Chapter (2): re-arranging and organizing the election that had been postponed. 


\section{Discussion}

The Government Policy through The Government Regulation in Lieu of Acts (Perpu) No. 2 of 2020 issued the legal foundation for General Elections Commission (KPU) to implement the continued regional election. However, covid-19 mitigation policies such as social distancing, physical distancing, PSM, large-scale social restriction (PSBB), and health protocol procedure of covid-19. All of those should well-prepared for people as voters, General Elections Commission (KPU) and Election Supervisory Agency (Bawaslu) as committees, regional government, military force/security force officials, political parties, and candidates. General Elections Commission (KPU) and Election Supervisory Agency (Bawaslu) must establish regulation adjustment to covid-19 health protocol and its policies, technical instructions, etc. Nevertheless, there is no guarantee to stimulate the success of applying health protocol with less 2 (two) months in current situation. In normal condition, the Election infringes still at high level, even in abnormal.

In sociology and psychology aspects, covid-19 policy implementation has influenced not only economics and social degradation, but also people's physics, where their livelihoods are restricted. Nowadays, regional election is contrary to "Genuine Elections" principle, i.e . The General Election held in social-politic conducive environment, where the human right freedom is revered and politic pluralism grew. The unsecured socio-economic and even health conditions will certainly influence the people's orientation and behaviour to participate Simultaneous Regional Election 2020.

Based on information published on the website of the General Election Commission (KPU) of the Republic of Indonesia, the campaign period for candidates of local head and vice is run on September 26, 2020 - December 5, 2020. Then, the current period is the right time for the people to know more closely the candidate for governor and vice of governor Central Kalimantan for the period 2021 - 2024. Therefore, all stakeholders are expected to work-hard and work-together that aims the people to choose the right leader.

Based on data in the KPU, the number of Final Voter Lists (DPT) in Palangka Raya, Central Kalimantan Province, is 178,231. The details are: voters in Bukit Batu Subdistrict are 8.723, voters in Jekan Raya Subdistrict are 93.093, voters in Pahandut Subdistrict are 60.674 people, 2.295 voters in Rakumpit Subdistrict, and 13.446 voters in Sabangau Subdistrict.

Based on the data, Jekan Raya Subdistrict has the most number of voters, meanwhile, Rakumpit Subdistrict has the lowest number of voters. With the inequality of voters in Palangka Raya, it is certainly a challenge for organizers of the election to make sure that all voters have access and convenience in using their right to vote during the Covid-19 pandemic. For example in the Rakumpit subdistrict, it locates far from Palangka Raya, and some of its areas must be through the river route. Those aspects would certainly be a challenge for the KPU of Palangka Raya to push the public to attend and vote at the polling stations (TPS).

The people believe that the organizers of the election can run direct elections on December 9, 2020. Based on the percentage, $72.6 \%$ of the people in Palangka Raya believe that the organizers of the election can run the election stages with tight health protocols. With this public trust, it is the right time for the Regional General Election Commission (KPUD) of Palangka Raya and the KPUD of Central Kalimantan to continue to strive for disseminating information to the people on the implementation of the local leader elections that will be held on December 9, 2020. It aims, the people could experient as expected in its implementation.

In this research, at least 208 Respondents on behalf of 5 (five) Districts and 30 (Thirty) Sub-Districts in Palangka Raya City, Central Kalimantan Province. They are final voter list 
(DPT) and have suffrage in regional election on December 9, 2020. The respondents percentage based on their age illustrated as follows:

Table 1. The respondents percentage based on their age

\begin{tabular}{|l|l|l|}
\hline NO & $\begin{array}{l}\text { Respondents Age Range } \\
\text { (Year) }\end{array}$ & Participation (Percent) \\
\hline 1. & $17-23$ & 35,8 \\
\hline 2. & $24-29$ & 13,9 \\
\hline 3. & $30-50$ & 31,3 \\
\hline 4. & $51-60$ & 11,1 \\
\hline 5. & $\geq 60$ & 7,9 \\
\hline
\end{tabular}

The table shows that the respondent majorities in Palangka Raya are 30-50 years old due to their frequent participants over the years. Therefore, any experiences in regional election has become a study. The administrative region of Palangka Raya Municipality consists of 5 (five) subdistrict and 30 (thirty) urban-village. They are Pahandut with 6 (six) urban-villages / villages, Sabangau with 6 (six) urban-villages / villages, Jekan Raya with 4 (four) urban-villages / villages, Bukit Batu with 7 (seven) urban-villages, and Rakumpit with 7 (seven) urban-villages / villages. The capital of the subdistrict in Palangka Raya Municipality is; the capital of Pahandut subdistrict is pahandut; the capital of Sebangau subdistrict is kalampangan; the capital of Jekan Raya subdistrict is palangka; the capital of Bukit Batu subdistrict is Tangkiling, and the capital of Rakumpit subdistrict is Mungku Batu.

Based on data published by the Central Bureau of Statistics (BPS) in 2019, the Population in Palangka Raya Municipality is 291.667. The population by religion is varied, but the majority is Islam and followed by Christian, belief, Hindu, Buddha, and Konghucu. Also, the population by the tribe is varied, for example, Dayak Tribe is the majority, and followed by other tribes, such as Banjar, Jawa, Bugis, Bali, and another tribe that migrated inhabitants.

From 208 Respondents in Palangka Raya City , Additionally, it is known that 92 '30 \% Respondents knew that governor regional election will be held on December 9, 2020, whereas about $7,70 \%$ is vice versa. Therefore, people whom have suffrage should know the regional election date in Central Kalimantan. Also, campaigns to every candidates in Palangka Raya are expected to be held via Offline, introducing their vision and mission directly by following the health protocol procedures. Moreover, Palangka Raya still have a low Internet access for virtual campaigns, so there would be a policies in campaigns via offline.

Other records disclosed that the role of Regional General Elections Commission (KPUD) to held candidate campaigns (Governor and Deputy) in Palangka Raya is bigger. This is because the implementation of regional election is very soon. The voting committees took extra-time to socialize the candidates via door to door due to the covid-19 pandemic by following the health protocol procedures. It is because the vision and mission of governor and deputy candidates period 2021-2024 in Central Kalimantan did not attract the people's attention.

From whole Respondents in Palangka Raya City, related to Public Perceptions either agree or disagree to implement simultaneous regional election on 9 December, 2020, the list are following: 
Table 2. The Respondent's Perception

\begin{tabular}{|l|l|l|}
\hline NO & The Respondent's Perception & Persentase $(\%)$ \\
\hline 1. & Very Agree & 7,2 \\
\hline 2. & Agree & 51,4 \\
\hline 3. & Disagree & 25,5 \\
\hline 4. & Very Disagree & 7,2 \\
\hline 5. & Blanks & 8,7 \\
\hline
\end{tabular}

The Data illustrated that respondent majorities in Palangka Raya agree to held simultaneous regional election on December 9, 2020. However, there are still a number of Palangka Raya People disagree. The Regional Election Committees (KPUD) must provide a clear information about regional election and its procedures in covid-19 current situation. Thus, they must convince the people that the regional election would undergo by following the health protocol to maximize the level of secure. The voting process in polling station (TPS) in current situation should be socialized by the committees. So, people feel safe to vote for their candidates. In addition, innovation of election supervisory agency (Bawaslu) to supervise the regional election is expected and considered to maintain the quality of the candidates and reduce of any infringes.

Besides, the supervision needs extra work to eliminate and minimize the opportunities for violations during the Covid-19 pandemic. It must not occur any violations in the mid of the covid-19 pandemic. Based on the data, $79.3 \%$ of the people believe that local leader elections during the Covid-19 pandemic run by organizers and supervisory agencies in a professional manner and neutrality. With a high level of trust from the people of Palangka Raya, it becomes evident that the quality of local leader elections during the Covid-19 pandemic could still be run without reducing the quality of elections itself.

\section{Conclusion}

Even though the covid-19 pandemic is still happening, in concludes that respondent majorities in Palangka Raya agree to held regional election on December 9, 2020. The health protocol procedures is highly expected to implement in regional election. A lack of socialization about voting procedures is a big challenge for election committees in current situation. It is their primary task to socialize simultaneous regional election that will be held on December 9, 2020, both via online and offline, due to the low signal to access the internet, particularly in Palangka Raya. Besides, there are a number of people meet problems to use online media. Therefore, socialization both Online and Offline in simultaneous regional election on December 9, 2020 is a vital need. The community hopes that regional head elections can be held honestly, fairly, transparently. 


\section{References}

Amrizal, D., et al. (2018). The Role of General Election Commission (KPU) in Increasing Voters' Participation in Langkat, Medan, Indonesia. Budapest International Research and Critics Institute-Journal (BIRCI-Journal), P. 13-24.

Arifulloh, A. (2015). Pelaksanaan Pemilihan kepala daerah Serentak Yang Demokratis, Damai dan Bermartabat. Jurnal Pembaharuan Hukum Volume II No. 2 Mei - Agustus $2015,302$.

Azhar, A.A. (2018). Marketing of Political Communication Created by National Mandate Party (PAN) in General Election 2005-2015, North Sumatra, Indonesia. Budapest International Research and Critics Institute-Journal (BIRCI-Journal), P. 93-106.

Winarno, Budi. 2014. Kebijakan Publik "Teori, Proses dan Studi Kasus". CAPS (Center Of Academic Publishing Service. Yogyakarta

Harahap, H. (2016). Evaluasi Pelaksanaan Pemilihan kepala daerah Serentak Tahun 2015. Jurnal Renaissance, 18.

Iryadi, I., et al. (2019). Muslim and Democracy: A Reflection from 2012 Aceh's Gubernatorial Election. Budapest International Research and Critics Institute-Journal (BIRCI-Journal), P. 545-555.

Kotler, P. (1995). Marketing Management Analysis, Planning, Implementation \& Control. Int: Prentice Hall.

Matondang, A., and Lubis, Y.A. (2018). Siladang Women and Regional Head Election in Mandailing Natal District, Indonesia. Budapest International Research and Critics Institute-Journal (BIRCI-Journal), P. 181-187.

Mufti, M. (2013). Teori-Teori Politik . Bandung: Pustaka Setia Bandung

Muliyana, D. (2017). Ilmu Komunikasi suatu Pengantar. Edisi Revisi. Bandung: Rosada

Rohmaul Listyana, Y. H. (2015). Persepsi dan Sikap Masyarakat Terhadap Penanggalan Jawa Dalam Penentuan Waktu Pernikahan (Studi Kasus Desa Jongrang Kecamatan Barat Kabupaten Magetan Tahun 2013). Jurnal Agastya Vol 5 No 1 Januari 2015, 121.

Sandi, J.R., Suprayitno (2020). Fenomena Pengawasan Pemilihan Kepala Daerah Di Kalimantan Tengah Masa Pandemi Covid-19. Jurnal Politik Pemerintahan Dharma Praja. volume 3 No.1

Sandi, J. R. (2019). Lembaga Adat dan Hak-Hak Masyarakat Adat Dayak Dalam Pusaran Politik (Studi Kasus Kalimantan Tengah 2011-2016). (R. S. Putra, Ed.) Tanggerang Selatan, Banten, Indonesia: Animage.

Sandi, J. R. (2020). Perilaku Politik Gereja Kristen Evangelis (GKE) dalam Pemilihan Umum Legislatif di Kalimantan Tengah Tahun 2019. Jurnal Politik Profetik Volume 8, No. 1 Tahun 2020, 46.

Suprayitno, S., Putri, F.P.P., Triyani, T. (2019). Strategy on the National Unity and Politics Agency (KESBANGPOL) in Maintaining Ethnicity and Religious Relations Based on Huma Betang Philosophy in Central Kalimantan. Budapest Internasional Research and Critics InstituteJournal (Birci-Journal. 2(3). 229-238. Doi: https://doi.org/10.33258/birci.v2i4.629

Surbakti, Ramlan \& Hari Fitrianto. (2015). Transformasi Bawaslu dan Partisipasi Masyarakat Dalam Pengawasan Pemilu. Jakarta: Kemitraan bagi Pembaharuan Tata Pemerintahan.

Surbakti, Ramlan. dkk (2008). Perekayasaan Sistem Pemilihan Umum: Untuk Pembangunan Tata Politik Demokratis. Jakarta: Kemitraan Bagi Pembaharuan Tata Pemerintahan Indonesia.

Yulika. (2016). Perception from the Members of Parliament Semarang. Journal of Politic and Government Studies, 2. 
Yusra, E. (2018). Persepsi Masyarakat Terhadap Mahyedi Ansharullah Dalam Menghadapi Pemilihan kepala daerah Serentak 2018 (Studi Kasus Di Kota Padang). Ranah Research Jurnal Multydisiplinary Research Development, 120.

https://infopemilu.kpu.go.id

https://palangkakota.bps.go.id

https://kalteng.bps.go.id/ 